DOI: 10.32844/2222-5374-2020-104-2.03

УДК: 343.8

Дмитращук О. C.,

здобувач Науково-дослідного інституту публічного права

\title{
КРИМІНОЛОГІЧНА ХАРАКТЕРИСТИКА ОСОБИ, ЯКА ВЧИНЯЄ ДОМАШНЄ НАСИЛЬСТВО
}

Актуальністьстаттіполягає в тому,щооднієюзі складовихпредмета кримінології є вчення про особу злочинця. Без нього важко дослідити інші кримінологічні проблеми, зокрема, детермінанти злочинів та засоби боротьби зними. Зодного боку, чинникизлочинності пов'язаніз об'єктивними соціальними явищами, які негативно впливають на формування особи $i$ проявляються в егоїстичних, антисуспільних поглядах і звичках, що лежать в основі кримінальної поведінки, а з іншого - з обставинами, що сприяють реалізації таких поглядів і звичок у конкретному злочині. Зазначені явища і обставини не залежать від людини, $є$ зовнішніми стосовно неї, але свого криміногенного значення вони набувають, формуючи особузлочинця і таким чином трансформуючись у внутрішні детермінанти злочину. Стаття присвячена кримінологічній характеристиці особи, яка вчиняє злочинні дії в сімейно-побутовому осередку. З'ясовано існуючі доктринальні підходи до розуміння категорій «особа-кривдник» та «особа злочинець», на основі чого обгрунтовано, що кривдником є особа, що вчиняє систематичне фізичне, психологічне або економічне насильство відносно подружжя чи колишнього подружжя або іншої особи, з якою особа перебуває (перебував) у сімейних або близьких відносинах. Визначено сочіально-демографічні властивості особи-кривдника, а саме: а) стать (переважна більшість осіб чоловічої статі); б) рівень освіти; в) вік; г) стан алкогольного сп'яніння; д) трудова зайнятість; $\epsilon$ ) наявність судимості. Встановлено кримінологічний портрет особи, яка вчиняє домашнє насильство (громадянин України чоловічої статі, 30-50 років, що має базову середню освіту, працездатний, але не працюючий, не судимий, схильний до вживання алкоголю). Резюмується, що особу, яка вчиняє домашнє насильство, слід віднести до насильницького типу особи злочинця, а за глибиною антисуспільної спрямованості до ситуаційнонестійких злочинців. Наголошено, що структура особи злочиния передбачає наявність трьох груп ознак (властивостей, якостей): 1) соціальнодемографічні (стать, вік, соціальне становище, рівень освіти, сімейний стан, рід занять тощо); 2) кримінально-правові (зміст і мотивація, одноосібний чи груповий характер злочинної діяльності, тривалість та інтенсивність злочинної діяльності, наявність чи відсутність судимості тощо); 3) соціально-психологічні властивості та якості осіб, які вчинили злочин (світогляд, інтереси та життєві установки).

Ключові слова: домашнє насильство, особа злочиния, особа-кривдник, соціально-демографічні властивості, кримінологічний портрет особи, насильницький тип особи злочинця. 
Актуальність теми. Однією зі складових предмета кримінології $€$ вчення про особу злочинця. Без нього важко дослідити інші кримінологічні проблеми, зокрема, детермінанти злочинів та засоби боротьби з ними. 3 одного боку, чинники злочинності пов'язані з об'єктивними соціальними явищами, які негативно впливають на формування особи і проявляються в егоїстичних, антисуспільних поглядах і звичках, що лежать в основі кримінальної поведінки, а 3 іншого - 3 обставинами, що сприяють реалізації таких поглядів і звичок у конкретному злочині. Зазначені явища і обставини не залежать від людини, є зовнішніми стосовно неї, але свого криміногенного значення вони набувають, формуючи особу злочинця і таким чином трансформуючись у внутрішні детермінанти злочину [1, c. 71].

Як зазначає I.M. Даньшин, особа злочинця - це складне інтегруюче поняття, що включає в себе і біологічні, і психологічні, і соціальні сторони людини [2, с. 34]. Однак, переконані, що, в першу чергу, особу злочинця слід розглядати як єдність соціологічного і юридичного аспектів цього явища правової дійсності. Не виключенням $є$ й дослідження характерних рис особи, що вчиняє домашнє насильство, з'ясування яких в умовах сучасності залишається актуальним питанням, що потребує здійснення подальших наукових розвідок.

Стан дослідження. Запобіганню домашньому насильству були присвячені наукові праці таких вітчизняних та зарубіжних вчених: О. Бандурки, В. Бондаровської, Т. Бугаєць, О. Ковальової, Л. Козуб, О. Кочемировської,

Г. Лактіонової, К. Левченко, Т. Малиновської, О. Суслової, E. Salisbury, G. Donavin та інших. Однак науковцями недостатньо уваги було приділено питанням кримінологічної характеристики особи, яка вчиняє домашнє насильство, що зумовлює необхідність проведення додаткових наукових пошуків у цій царині.

Метою статті $є$ сформувати кримінологічний портрет особи, яка вчиняє домашнє насильство, шляхом визначення його характерних рис.

Виклад основного матеріалу. Принагідно зазначимо, що в кримінологічній науці розуміння категорії «особа-кривдник» характеризується полісемічністю.

Так, наприклад, з погляду Л.В. Самарай, особа кривдника - це наслідок вчинення протиправної діяльності, а не тип людини, який їй передує. Логічно, що в цьому випадку проблематичним $є$ визначення норм, відповідно до яких позначають злочинність чи не злочинність діяння. Адже норма фіксує безумовний мотив. Є люди, які народжуються з певними генетичними й психологічними вадами, що за несприятливих умов середовища може стати фактором, який провокує агресивну поведінку, наслідком якої може стати (а може й не стати) вчинення насильницьких дій. Але це відбувається лише в тому разі, якщо є сукупність соціальних детермінант, які відіграють роль збудників такої поведінки [3, с. 191].

На переконання I.А. Ботнаренко, особу злочинця, який вдається до насильства в сім'ї, слід розуміти як особу, що вчиняє умисні насильницькі дії фізичного, сексуального, психологічного чи економічного характеру відносно члена (членів) своєї сім'ї. Відповідно, кримінологічна характерис- 
тика такої особи - це кримінологічний опис комплексу соціально значущих ознак особи, наділеної такими якостями з огляду на її взаємодію із зовнішніми умовами й обставинами, що зрештою призводить до вчинення нею актів насильства відносно члена (членів) сім'ї [4, с. 84].

Проте з визначенням I.A. Ботнаренко слід не погодитись, адже, воно не відповідає нормативним положенням ст. 126-1 КК України. Тому вважаємо, що кривдника більш коректно розуміти як особу, що вчиняє систематичне фізичне, психологічне або економічне насильство відносно подружжя чи колишнього подружжя або іншої особи, з якою особа перебуває (перебував) у сімейних або близьких відносинах.

Задля повного та об'єктивного дослідження особи-кривдника, що вчиняє домашнє насильство, обов'язковим $є$ з'ясування його структурних елементів. 3 цього приводу загальноприйнятим $\epsilon$ підхід, що структура особи злочинця передбачає наявність трьох груп ознак (властивостей, якостей): 1) соціально-демографічні (стать, вік, соціальне становище, рівень освіти, сімейний стан, рід занять тощо); 2) кримінально-правові (зміст і мотивація, одноосібний чи груповий характер злочинної діяльності, тривалість та інтенсивність злочинної діяльності, наявність чи відсутність судимості тощо); 3) соціально-психологічні властивості та якості осіб, які вчинили злочин (світогляд, інтереси та життєві установки) [5, с. 97].

Проте А.Б. Благою, з точки зору методології структурного аналізу, запропоновано дещо інший підхід, що передбачає такі елементи: соціальнодемографічні, кримінально-правові, соціально-рольові та моральнопсихологічні [6, с. 92].

Соціально-демографічні властивості особи злочинця пов'язані 3: умовами формування особи та її життєдіяльності, потребами і мотивацією, соціальними ролями і статусом особи, тому вони є істотним елементом поняття особи злочинця і мають важливе значення для розробки i здійснення заходів профілактики [7, с. 34].

Першим показником соціально-демографічних властивостей особикривдника домашнього насильства уважаємо стать. Відповідно до даних Державної судової адміністрації України за 2019 рік домашнє насильство вчинили 159 осіб, з них 151 особа (95\%) чоловічої статі та 8 (5\%) осіб жіночої статі. За січень-листопад 2020 року домашнє насильство вчинили 149 осіб, з яких 134 (90 \%) особи чоловічої статі та 15 (10\%) осіб жіночої статі. Отже, як бачимо, переважна більшість кривдників особи чоловічої статі.

Окремої уваги заслуговує і жіноча злочинність в побутовій сфері. Адже, незважаючи на те, що даний вид злочинності в жодному суспільстві немає домінуючого характеру, його рівень і структура $\epsilon$ показниками морального здоров'я суспільства, індикаторами його духовності, ставлення до основних людських цінностей тощо [8, с. 189].

Так, Г.М. Філоненко, аналізуючи злочини, що вчиняються жінками у сімейно-побутовій сфері, дійшла до висновку, що найбільшу групу складають злочини проти життя та здоров'я особи, спрямовані проти чоловіків або співмешканців, що вчиняються активними діями з умисною формою вини [9, с. 156]. 3 результатами дослідженням Т.М. Продана, питома вага зазначених злочинів становить $(60,8$ \%) [10, с. 311], а загаль- 
ний відсоток жіночої злочинності у суспільстві коливається в межах 1012 \% від усієї злочинності [11, с. 193]. Жертвами злочинів, що вчиняються жінками можуть стати: чоловіки, співмешканці, коханці, колишні чоловіки; діти; батьки, родичі; друзі і сусіди [12, с. 73].

Однією з соціально-демографічних властивостей особи-кривдника уважаємо її рівень освіти.

Подібних висновків доходять багато кримінологів, якими зауважується, що найбільше випадків домашнього насильства вчиняють особи, які мають повну та неповно загальну середню освіту (56\%), середню спеціальну (36 \%), і початкову вищу (3\%). Невелика кількість нападників мають повну вищу освіту (5 \%) або взагалі не мають жодної [13, с. 390].

Аналізуючи звіт Державної судової адміністрації за 2019 рік можемо побачити, що у 5 осіб (3,1 \%) була повна вища освіта, у 1 особи (0,6 \%) базова вища, у 37 осіб (23,3 \%) професійна (професійно технічна), у 86 осіб (54 \%) повна загальна середня, у 29 осіб (18,2 \%) базова загальна середня, без освіти лише 1 особа (0,6 \%) [17]. Відповідно до звіту про осіб, які вчинили кримінальні правопорушення за січень-листопад 2020 року встановлено, що у 4 (2,7 \%) осіб була вища або фахова передвища освіта, у 32 (21,5 \%) осіб професійна (професійно технічна), у 112 осіб (75,1\%) базова середня та профільна середня та лише у 1 особи $(0,7$ \%) була початкова освіта. Вказана статистика свідчить про те, що рівень освіти безпосередньо впливає на кількість випадків домашнього насильства, адже лише 4 (2,7 \%) особи із 149 осіб мали вищу або фахову передвищу освіту.

Наступним показником соціально-демографічних властивостей особи-кривдника, що вчиняє домашнє насильства є вік.

Вікова характеристика злочинців дає змогу дійти висновку про ступінь інтенсивності прояву криміногенної активності та особливості злочинної поведінки представників різних вікових груп [14, с. 34].

Як зазначає А.Б. Блага пік кримінальної активності осіб, які вчинили злочини, пов'язані з насильством в сім'ї, припадає на дві вікові категорії - 21-29 роки, що становить 29 \% від загальної маси, та 30-39 років, що складає $26,9 \%$ [15, с. 96].

Згідно звіту Державної судової адміністрації за 2019 рік віковий ценз особи-кривдника був наступний: $18-25$ років - 3 особи $(1,9 \%), 25-30$ років - 15 осіб (9,4\%), 30-50 років - 108 осіб (67,9\%), 50-65 років - 32 особи $(20,1 \%), 65$ років і старше - 1 особа (0,6 \%) [17]. Відповідно звіту про осіб, які вчинили кримінальні правопорушення за січень-листопад 2020 року встановлено, що серед загальної кількості осіб, які вчинили домашнє насильство 18-28 років становило 11 осіб (7,4\%), 29-39 років - 52 особи $(34,9 \%), 40-54$ років - 71 особа $(47,6 \%), 55-59-8$ осіб $(5,4 \%), 60$ років і більше - 7 осіб $(4,7 \%)$ [18].

Ураховуючи, що у зазначених звітах віковий ценз різниться, вважаємо за необхідне вивести середнє арифметичне. Таким чином, зазначена вище статистика дає змогу стверджувати, що більша кількість осіб, що вчиняють домашнє насильство припадає на 30-50 років.

Із звіту Державної судової адміністрації за 2019 рік встановлено, що 81 особа (51 \%) вчинила домашнє насильство в стані алкогольного сп'яніння. Що становить більше половини загальної кількості [17]. Відповідно зві- 
ту про осіб, які вчинили кримінальні правопорушення за січень-листопад 2020 року встановлено, що 59 осіб (39,6 \%) вчиняли домашнє насильство в стані алкогольного сп'яніння, 6 осіб (4\%) в стані алкогольного сп'яніння повторно [18].

Вказані дані дають підстави стверджувати, що алкогольне сп'яніння сприяє вчиненню домашнього насильства, як і будь-якому іншому злочину.

Також встановлено, що за січень-листопад 2020 року, із загальної кількості осіб-кривдників 39 осіб раніше вчиняли кримінальні правопорушення, що становить 26,2 \%, майже одна четверта частина. Судимість не знята та не погашена була у 32 осіб (21,5 \%). Дві особи (1,3\%) раніше вчиняли домашнє насильство, судимість за яке не знята і не погашена. Наголосимо, що всі випадки домашнього насильства за звітний період були вчинені одноосібно [18].

Розглядаючи соціально-психологічні властивості та якості особикривдника, який вчиняє домашнє насильство необхідно звернути увагу на соціальну площину. Соціальна площина агресії відзначається тим, що в суспільстві вона не виникає без певних мотивів і настанов, і тому це явище більш складне, аніж агресія в тваринному середовищі. В суспільстві агресія постає як насильство і пояснюється тими соціальними відносинами, які склались в суспільстві, а високий або низький рівень агресивності особистості виступає результатом їі соціалізації [16, с. 189].

Аналізуючи звіт Державної судової адміністрації за 2019 рік можемо побачити, що переважна більшість, а це 143 особи (89,9 \%) не працювали і не навчались. Робітники становили - 8 осіб (5\%), пенсіонери - 4 особи $(2,5 \%)$, безробітні - 2 (1,2 \%), інші види занять також - 2 особи $(1,2 \%)$. У 2020 році простежується така ж сама тенденції безробіття. Встановлено, що 133 особи (89,3 \%), які вчинили домашнє насильство були працездатні, але не працюють і не навчаються [18].

Отже, надмірна кількість вільного часу, відсутність зайнятості, небажання до суспільно-корисної праці та самовдосконалення, тільки сприяє вчиненню домашнього насильства.

Погоджуємось із твердження А.Б. Благи, що кардинальні зміни соціально-економічної ситуації в країні торкнулися також сфери зайнятості та організації освіти (в нашому випадку, маємо на увазі запровадження карантину з метою запобігання поширенню на території України гострої респіраторної хвороби COVID-19, спричиненої коронавірусом SARS-CoV-2), що, у свою чергу, вплинуло і на розподіл злочинців досліджуваної категорії за родом занять. На момент вчинення злочину переважна більшість сімейних кривдників не працювали і не навчались, перебивались тимчасовими заробітками. Домінування цих категорій може свідчити про значимість трудової дезадаптації як фактору злочинної поведінки [15, с. 102].

Висновки. Отже, враховуючи вищевикладене, маємо змогу сформувати кримінологічний портрет особи, яка вчиняє домашнє насильство: це громадянин України чоловічої статі, 30-50 років, що має базову середню освіту, працездатний, але не працюючий, не судимий, схильний до вживання алкоголю.

Кримінологічна характеристика особи-кривдника, який вчиняє домашнє насильство, вимагає дослідження й питання його типологізації. 
Поділяємо позицію більшості кримінологів, які вважають, що підставами (критеріями) для класифікації особи-злочинця є: характер антисуспільної спрямованості особи злочинців; ступінь глибини цієї антисуспільної спрямованості. Перший тип включає: насильницький, корисливий, злісний, а також необережний тип злочинців. Другий тип включає: випадкових, ситуаційних, нестійких, злісних та особливо злісних злочинців [2, c. 40-41].

Зважаючи на вказане, особу, яка вчиняє домашнє насильство, необхідно віднести до насильницького типу особи злочинця, для якого характерне зневажливе ставлення до іншої особи. За глибиною антисуспільної спрямованості особу-кривдника, який вчиняє домашнє насильство, необхідно віднести до ситуаційно-нестійких злочинців.

\section{СПИСОК ВИКОРИСТАНИХ ДЖЕРЕЛ}

1. Кримінологія : підручник для студентів вищих навч. закладів / за заг. ред. О.М. Джужи. Київ : Юрінком Інтер, 2002. 416 с.

2. Кримінологія: Загальна та Особлива частина : підручник / за заг. ред. В.В. Голіни. Харків : Право, 2009. 288 с.

3. Самарай Л.В. Кримінологічна характеристика особи кривдника, який вчинив сімейне насильство під впливом агресії. Науковий вісник Національної академії внутрішніх справ. 2013. № 1. С. 190-197.

4. Ботнаренко I.А. Кримінологічна характеристика осіб, які вчиняють насильство в сім'ї. Науковий вісник Національної академії внутрішніх справ. 2017. № 2 (103). С. 83-96.

5. Біленко С.П. Кримінологічна характеристика кривдника. Вісник Луганського державного університету внутрішніх справ ім. Е.О. Дідоренко. 2019. Вип. 2 (86). С. 95-105.

6. Блага А.Б. Насильство в сім'ї (кримінологічний аналіз і запобігання) : монографія. Харків : Ф0-П Макаренко, 2014. 360 с.

7. Кримінологія : навч. посіб. / за заг. ред. О.М. Джужи. Київ : Прецедент, 2006. 198 с.

8. Гаргат-Українчук О.М. Кримінологічна характеристика жіночої злочинності. Науковий вісник Ужгородського національного університету. Серія Право. 2014. Вип. 25. С. 189-191.

9. Філоненко Г.М. Класифікація злочинів, що вчиняються жінками у сімейно-побутовій сфері. Наше право. 2014. № 8. С. 150-156.

10. Продан Т.В. Стан жіночої насильницької злочинності в України. Право і суспільство. 2014. № 5-2. С. 303-311.

11. Філіпенко В.О. Кримінологічна характеристика злочинності жінок у побутовій сфері. Юридичний науковий електронний журнал. 2018. № 1. С. 193-196.

12. Філоненко Г.М. Жертви злочинів, що вчиняються жінками у сімейно-побутовій сфері. Наше право. 2014. № 9. С. 72-77.

13. Лук'янова Ю.О. Кримінологічна характеристика осіб, що вчиняють домашнє насильство, та шляхи запобігання вчиненню цього злочину. 2018. № 4. С. 388-391.

14. Кримінологія : навчальний посібник / за заг. ред. О.М. Джужи. Київ : Атіка, 2010. 312 с. 
15. Блага А.Б. Насильство в сім'ї (кримінологічний аналіз і запобігання) : монографія. Харків : ФО-П Макаренко, 2014. 360 с.

16. Качмар О.В. Вплив соціального макро- і мікросередовища на прояви агресивності особистості. Гуманітарний вісник ЗДІА. 2016. № 66. С. 183191.

17. Склад засуджених осіб за судовими рішеннями, що набрали законної сили за 2019 рік. Судова влада України. URL: https://court.gov.ua/ inshe/sudova_statystyka/nasilstvo_19

18. Склад засуджених за судовими рішеннями, що набрали законної сили за 2020 рік. Судова влада України. URL: https://court.gov.ua/inshe/ sudova_statystyka/rik_2020

\section{O. Dmytrashchuk}

\section{CRIMINOLOGICAL CHARACTERISTICS OF A PERSON WHICH DOES DOMESTIC VIOLENCE}

The relevance of the article is that one of the components of the subject of criminology is the doctrine of the identity of the offender. Without it, it is difficult to investigate other criminological problems, in particular, the determinants of crimes and means of combating them. On the one hand, the factors of crime are related to objective social phenomena that negatively affect the formation of personality and are manifested in selfish, anti-social views and habits that underlie criminal behavior, and on the other - with the circumstances that contribute to the implementation of such views and habits in a particular crime. These phenomena and circumstances do not depend on the person, are external to him, but they acquire their criminogenic significance, forming the identity of the offender and thus transforming into internal determinants of the crime. The article is devoted to the criminological characteristics of a person who commits criminal acts in a family home. The existing doctrinal approaches to understanding the categories «offender» and «offender» are clarified, on the basis of which it is substantiated that the offender is a person who commits systematic physical, psychological or economic violence against a spouse or ex-spouse or another person with whom the person is (was) in a family or close relationship. The socio-demographic characteristics of the offender are determined, namely: a) sex (the vast majority of people are men); b) level of education; c) age; d) state of alcohol intoxication; e) employment; $g$ ) the presence of a criminal record. Has been established a criminological portrait of a person who commits domestic violence (a male citizen of Ukraine, 30-50 years old, with a basic secondary education, able to work, but not working, not convicted, prone to alcohol consumption). It is concluded that a person who commits domestic violence should be classified as a violent type of criminal, and by the depth of anti-social orientation to situational unstable criminals. It is emphasized that the structure of the offender's personality presupposes the presence of three groups of characteristics (properties, qualities): 1) socio-demographic (sex, age, social status, level of education, marital status, occupation, etc.); 2) criminal law (content and motivation, individual or group nature of criminal activity, duration and intensity of criminal activity, presence 
or absence of a criminal record, etc.); 3) socio-psychological properties and qualities of persons who have committed a crime (worldview, interests and attitudes).

Keywords: domestic violence, person of the criminal, person-offender, sociodemographic characteristics, criminological portrait of the person, violent type of person of the criminal. 